\title{
Effects of soil management systems on soil microbial activity, bulk density and chemical properties(1)
}

\author{
Maria Alexandra Reis Valpassos ${ }^{(2)}$, Eloiza Gomes Silva Cavalcante ${ }^{(3)}$, \\ Ana Maria Rodrigues Cassiolato(4) and Marlene Cristina Alves ${ }^{(3)}$
}

\begin{abstract}
The objective of this experiment was to study the effects of soil management systems on the bulk density, chemical soil properties, and on the soil microbial activity on a Latossolo Vermelho distrófico (Oxisol). Soil samples were collected from plots under the following management conditions: a) natural dense "cerrado" vegetation (savanna); b) degraded Brachiaria decumbens pasture, 20 years old; c) no-tillage treatment with annual crop sequence (bean, corn, soybean and dark-oat in continuous rotation), 8 years old; d) conventional tillage treatment with crop residues added to the soil, and annual crop sequence, 10 years old. The continuous use of no-tillage system resulted in an increase in microbial biomass and decrease in soil basal respiration, therefore displaying evident longterm effects on the increase of soil $\mathrm{C}$ content. The no-tillage system also provided an improvement in bulk density and chemical properties of the soil. Hence, the no-tillage management system could be an alternative for the conservation and maintenance of physical and chemical conditions and the productive potential of "cerrado" soils.
\end{abstract}

Index terms: soil chemicophysical properties, biomass, soil deterioration, soil conservation

Efeitos de sistemas de uso e manejo na atividade microbiana, densidade e propriedades químicas do solo

Resumo - Este trabalho teve por objetivo estudar os efeitos de diferentes sistemas de uso e manejo na densidade do solo nas suas propriedades químicas e na atividade microbiana em um Latossolo Vermelho distrófico (Oxisol). As amostras de solo foram retiradas de parcelas dos seguintes tratamentos: cerrado denso preservado, pastagem de Brachiaria decumbens degradada (20 anos), plantio direto com rotação de culturas ( 8 anos) e sistema convencional com rotação de culturas anuais (10 anos). $\mathrm{O}$ delineamento experimental utilizado foi o inteiramente casualizado, com dez repetições. O uso contínuo de plantio direto resultou em mais alta taxa de C-biomassa microbiana e menor perda relativa de carbono pela respiração basal, podendo determinar, desta forma, maior acúmulo de $\mathrm{C}$ no solo a longo prazo. Proporcionou, ainda, melhoria na densidade aparente e nas propriedades químicas do solo. Assim, o sistema plantio direto, com manejo de culturas, mostrou ser uma alternativa para a conservação e manutenção das condições físicas e do potencial produtivo de solos de cerrado.

Termos para indexação: propriedades físico-químicas do solo, biomassa, degradação do solo, conservação do solo.

\section{Introduction}

"Cerrado" vegetation fits into the category of the savanna formation. The "cerrado" areas are about

(1) Accepted for publication on February 28, 2001.

(2) Universidade Estadual Paulista (Unesp), Dep. de Biologia, Caixa Postal 31, CEP 15385-000 Ilha Solteira, SP. E-mail: marv@fcav.unesp.br

(3)Unesp, Fac. de Engenharia, Dep. de Ciências do Solo e Eng. Rural, Caixa Postal 31, CEP 15385-000 Ilha Solteira, SP. E-mail: mcalves@agr.feis.unesp.br

(4)Unesp, Fac. de Engenharia, Dep. de Biologia, Caixa Postal 31, CEP 15385-000 Ilha Solteira, SP. E-mail: anamaria@agr.feis.unesp.br
$25 \%$ of the total Brazilian territory, and they have a fundamental role on the concentration and balance of almost all biological systems. If these "cerrado" areas are used improperly, they can cause deep changes on the ecosystem, due to their edaphic climaxes characteristics. After the 1960's, an extensive occupation process started on several areas of Brazilian "cerrado" which involved intensive agricultural, pasture and reforestation activities. Those unplanned activities degraded approximately $75 \%$ of all their extension, and the destruction and/or devastation were mainly caused by extensive pasture, large crop farms, and the building of several dams for electric purposes (World Wild Fund for Nature, 1995). 
The continuous growth of an only crop may cause serious changes in the natural ecosystem equilibrium. The types of soil and crop management have direct influence on the physical, chemical and biological soil conditions. Different management techniques can denote different substrate availability, which may benefit or inhibit the establishment of different microbial groups (Cardoso et al., 1992).

The maintenance of the ecosystem productivity depends mainly on the organic matter transformation and, consequently, on the soil microbial biomass. Soil microbes are the base of a complex food web with links to aboveground ecosystems. In addition, the microbial biomass represents a rapidly recycled pool of available nutrients that can be used by plants. Changes in the structure of microbial communities may lead to changes of important functions such as organic matter decomposition and pollutant degradation (MacAlady et al., 1998).

Microorganisms inhabit soil and, together with exocellular enzymes and soil mesofauna and macrofauna, conduct all known metabolic reactions. These organisms play a key role in the composition of soil organic matter and nutrient cycling and, therefore, microbial activity is very important for the maintenance of soil fertility. Microbial activities comprise all biochemical reactions catalyzed by microorganisms in the soil, and the integrity of the metabolic capacity of the soil microflora is a fundamental requirement for any concept of soil protection, soil bioremediation and recultivation (Alef \& Nannipieri, 1995). The soil microbial biomass comprises only $1 \%$ to $3 \%$ of the total organic $\mathrm{C}$ in the soil, but is a relatively labile fraction of soil organic matter (Jenkinson \& Ladd, 1981). Further, it responds more rapidly to changes in organic matter input or rate of decomposition than the soil organic matter as a whole (Powlson \& Jenkinson, 1981; Powlson et al., 1987).

There is a worldwide interest in the retention of crop residues in the soil. Their retention alters soil properties, mainly by causing a gradual increase in soil organic matter content. However, such changes are slow and therefore difficult to measure accurately against the large background of organic matter present in most of the soils (Powlson \& Jenkinson, 1981). The soil microbial biomass responds as a whole to changes in agricultural practices which al- ter the annual input of organic matter into the soil. It can give an early warning of the direction of longterm changes in soil organic matter content long before they can be detected by conventional techniques (Saffigna et al., 1989). Measurements of microbial activity in soils are based on the presence of intact and active microbial cells; they reflect the physiological state of microbial cells (Alef \& Nannipieri, 1995). Therefore, biomass measurements can be used to give an indication of long-term differences in soil organic matter among contrasted treatments in the field, as well as they may represent important ecological indicator (Jenkinson \& Ladd, 1981).

The present paper aimed to study the effects of different soil management systems on the bulk density and chemical soil properties and on the soil microbial activity.

\section{Material and Methods}

The study was carried out at the São Paulo State University (Unesp) Research Station located at Selvíria, MS, Brazil (latitude $20^{\circ} 22^{\prime} \mathrm{S}$, longitude $51^{\circ} 22^{\prime} \mathrm{W}$ and altitude $335 \mathrm{~m}$ ). According to Köppen's classification, the climate is Aw, with average annual precipitation of $1,370 \mathrm{~mm}$, mostly concentrated between October and March. The average annual temperature is $23.7^{\circ} \mathrm{C}$, and the mean annual relative humidity is $70 \%$ to $80 \%$. The regional soil type is on Latossolo Vermelho distrófico (Oxisol) (Embrapa, 1999). The soil at the depth of $0-10 \mathrm{~cm}$ had: $470 \mathrm{~g} / \mathrm{kg}$ of clay, $480 \mathrm{~g} / \mathrm{kg}$ of sand and $50 \mathrm{~g} / \mathrm{kg}$ of silt.

Soil samples were obtained in July 1998 from four different plots established at the following treatments: a) natural dense "cerrado" vegetation (savanna); b) degraded pasture: the pasture area was established in 1978 and has been in use for 20 years. It is covered with Brachiaria decumbens, and fertilizers and limestone were applied only at its establishment; c) no-tillage treatment: this area was regularly irrigated and cultivated for the last eight years on the crop rotation schedule using: bean (Phaseolus vulgaris), corn (Zea mays L.), soybean (Glycine max (L.) Merrill) and dark oat (Avena strigosa Schieb). Weeds are controlled with herbicides; d) conventional tillage treatment with crop residues added to the soil, and annual crop sequence (continuous rotation with soybean and corn) using plough and flatten harrow implements for soil preparation (10 years old). At the no-tillage and conventional tillage treatment areas, $200 \mathrm{~kg} /$ ha of a $4-30-10$ fertilizer were applied. 
After removing the loose unincorporated litter from the soil surface, the random soil samples were organized to cover all the dimension of each treatment core area The 10 composed soil samples were taken from the $10 \mathrm{~cm}$ soil depth, and each sample consisted of four separate soil core areas. The samples were placed in plastic bags and immediately stored at $24^{\circ} \mathrm{C}$ for 24 hours in the laboratory. Before analysis, the soil samples were sieved to pass a $2 \mathrm{~mm}$ screen, and $20 \mathrm{~g}$ of soil samples were oven-dried for 24 hours and weighed to determine the water holding capacity. Then, the $70 \%$ field capacity was calculated to determine the $\mathrm{C}$ from soil basal respiration and from microbial biomass. All treatments within a replicate, one for each soil sample, were performed on the same day in order to prevent variation due to length of storage.

Bulk density was determined according to Blake (1965). The soil chemical analysis were performed according to Raij \& Quaggio (1993) and Tomé Júnior (1997): total organic matter $(\mathrm{OM})$ based on colorimetry method; resin extractable $\mathrm{P}$ and $\mathrm{Al}$; cation exchange capacity (CEC) based on the sum of exchangeable $\mathrm{Ca}, \mathrm{Mg}, \mathrm{K}, \mathrm{H}+\mathrm{Al}$. The $\mathrm{H}+\mathrm{Al}$ were extractables hydrogen, by calcium acetate $1 \mathrm{~N}$. The sum of bases (SB) was calculated by the formula: $\mathrm{SB}=\mathrm{Ca}+\mathrm{Mg}+\mathrm{K}$ and the base saturation (V) by the formula: $\mathrm{V}=100$ (SB/CEC)

Basal soil respiration was determined by placing $100 \mathrm{~g}$ of soil from each sample into wide-neck screw-top glass jars $(1,000 \mathrm{~mL})$ together with $10 \mathrm{~mL} 0.1 \mathrm{~N} \mathrm{NaOH}$ in $20 \mathrm{~mL}$ glass vials. The soil was remoistened to $70 \%$ of field capacity, in order to offset the drying effect of the alkali. The glass jars were screwed down with the original cap and sealed with layers of paraffin. Blank incubations, in which the jar contained $\mathrm{NaOH}$ but no soil, were included in the experiment. All samples were incubated for five days at $25^{\circ} \mathrm{C}$, and the $\mathrm{CO}_{2}$ evolved and trapped during the period was determined by titration of the $\mathrm{NaOH}$ with $0.1 \mathrm{~N} \mathrm{HCl}$ (Jenkinson \& Powlson, 1976).

Carbon microbial biomass was measured using the chloroform fumigation-extraction method (Powlson et al., 1987). Soil was taken from each sample and placed into plastic bags: $10 \mathrm{~g}$ were fumigated and $10 \mathrm{~g}$ left unfumigated. The fumigation was done in large desicca- tors lined with moist paper. Each desiccator contained a beaker with $25 \mathrm{~mL}$ of ethanol-free $\mathrm{CHCl}_{3}$ and a few antibumping granules. The desiccator was evacuated until the $\mathrm{CHCl}_{3}$ boiled vigorously, after which the tap was closed and the desiccator was left in the dark at $25^{\circ} \mathrm{C}$ for 24 hours. The beaker with $\mathrm{CHCl}_{3}$ and the paper were then removed and the $\mathrm{CHCl}_{3}$ vapor eliminated from the soil by repeated evacuation in the desiccator. Six 3-min evacuations, with a high vacuum oil pump, were usually enough to remove $\mathrm{CHCl}_{3}$ from the soil. While fumigation was in progress, the unfumigated samples (controls) were kept at $6^{\circ} \mathrm{C}$ in the refrigerator.

Briefly after, fumigated and unfumigated soil samples were extracted with $40 \mathrm{~mL} 0.5 \mathrm{M} \mathrm{K}_{2} \mathrm{SO}_{4}$ on a rotary shaker at $150 \mathrm{rpm}$ for $30 \mathrm{~min}$ (Vance et al., 1987), centrifuged for $3 \mathrm{~min}$, and then filtered through Whatman № 1 filter paper. All filtered soil extracts were kept in the refrigerator $\left(4^{\circ} \mathrm{C}\right)$ until analysis. Organic $\mathrm{C}$ from the soil extracts was measured by $\mathrm{K}_{2} \mathrm{Cr}_{2} \mathrm{O}_{7}$ digestion followed by titration with $\mathrm{FeSO}_{4}$. C-biomass was calculated assuming $\mathrm{C}$-biomass $=2.64 \mathrm{Ec}$, where $\mathrm{Ec}$ is the difference between $\mathrm{C}$ extracted from the fumigated and non-fumigated treatments (Vance et al., 1987), and expressed in $\mu \mathrm{g} \mathrm{C} \mathrm{g}^{-1}$ soil.

The results are mean of ten samples. The study was carried out in a completely randomized design and the data were analyzed statistically. When a significant $F$ value was detected, the means were compared to control values by the Tukey test, with significance level set at 5\%.

\section{Results and Discussion}

The values of the extractable $\mathrm{Ca}, \mathrm{Mg}, \mathrm{CEC}$ and $\mathrm{V}$ were very high on no-tillage comparing to the other treatments, indicating a high content of exchangeable cations in this surface layer $(0-10 \mathrm{~cm})$ (Table 1$)$. This may be attributed to the great influence of the no-tillage system on the microbial activity, and so on the biological cycling of nutrients at this soil depth, once the first few centimeters of soil are closely related to the bio-cycling processes reflecting action (Vitousek \& Sanford Junior, 1986).

Table 1. Soil chemical properties on different soil management systems, at 0-10 $\mathrm{cm}$ depth.

\begin{tabular}{lcccrrrrrrr}
\hline $\begin{array}{l}\text { Soil management } \\
\text { system }\end{array}$ & $\begin{array}{c}\mathrm{pH} \mathrm{em} \\
\mathrm{CaCl}_{2}\end{array}$ & $\begin{array}{c}\mathrm{P} \\
\left(\mathrm{mg} \mathrm{dm}^{-3}\right)\end{array}$ & \multicolumn{1}{c}{$\mathrm{K}$} & \multicolumn{1}{c}{$\mathrm{Ca}$} & $\begin{array}{c}\mathrm{Mg} \\
\left(\mathrm{mmol}_{\mathrm{c}} \mathrm{dm}^{-3}\right)\end{array}$ & $\mathrm{Al}$ & $\mathrm{SB}$ & $\mathrm{CEC}$ & $\mathrm{V}(\%)$ \\
\hline No-tillage & 5.31 & 35.26 & 4.6 & 41.9 & 29.2 & 33.0 & 0.5 & 75.7 & 108.7 & 69.64 \\
Cerrado & 3.98 & 6.86 & 0.8 & 9.1 & 2.2 & 44.4 & 10.2 & 12.1 & 56.5 & 21.41 \\
Conventional & 5.13 & 16.18 & 1.2 & 24.0 & 9.8 & 26.6 & 0.9 & 35.0 & 61.6 & 56.81 \\
Pasture & 5.07 & 10.16 & 0.6 & 18.3 & 6.1 & 23.8 & 0.7 & 25.0 & 48.8 & 51.22 \\
\hline
\end{tabular}


Also, the accentuated accumulation of $\mathrm{P}$ on notillage system was remarkable compared with other treatments. On the other hand, the lower ratios of $\mathrm{Ca}$ and $\mathrm{K}$ observed at the pasture or the medium ratios of these nutrients observed for conventional tillage probably occurred due to the losses caused by soil erosion and crop residues incorporation (Rheinheimer et al., 1998). In Brazil, many type of soil is phosphate-limited for plant production. The larger inert reservoir of this mineral has been phosphate rock, but this reservoir is being increasingly tapped by the fertilizer industry. Usually, small and actively cycled reservoirs of phosphate are dissolved in living and dead organic matter. Most microbial P transformations are performed as a transfer of inorganic to organic phosphate or as transfer of phosphate from insoluble, immobilized forms to soluble or mobile compounds (Atlas \& Bartha, 1993). Therefore, the results observed on the no-tillage system can be explained by the fact that the soil on this system usually provides a vertical deposition of crop residues, once it is not periodically revolved as well as it presents high microbial activities (Table 1).

There were significantly differences on soil bulk densities for all management systems (Table 2). Usually, when soils are cultivated, significant changes occur in their structure, which are reflected on the mass/volume ratio and, as a consequence, the bulk density increases and the porosity decreases, specially the macropores. Once that soil is not revolved periodically on no-tillage systems, it may lead to a low compaction at the soil surface layer for some period (Sidras et al., 1982). This was also observed in this study. Natural "cerrado" used as control treatment showed a bulk density value of $1,180 \mathrm{~g} \mathrm{~cm}^{-3}$ and was followed by conventional, no-tillage system and degraded pasture which showed bulk density value of
$1,260,1,321$ and $1,598 \mathrm{~kg} \mathrm{~m}^{-3}$, respectively. Comparing those different soil management systems, results from conventional tillage showing soil with lower bulk density ratio than in no-tillage system, probably was due to the fact that in a conventional preparation, the soil has the surface layers periodically revolved. However, after long-period, the notillage system increases water infiltration; soil surface protection against erosion; water retention by the plus lower evaporation due to the presence of plant residues; aeration and porosity after the root depth; soil organic matter contents which increases the aggregates stability, microbial activities, soil fertility and nutrient turnover (Baldock \& Kay, 1987).

It is known that agricultural tillage systems have marked influence on both the content and distribution of organic matter within a soil profile. Various long-term field studies have demonstrated the strong stratification of soil organic matter with depth of soils under no-tillage management, as well as the apparent increase in the amount of organic matter in the soil surface (Belvins et al., 1984). The importance of microbial biomass in assessment of soil quality related to plant growth is established by the important role of soil microorganisms in nutrient cycling within agricultural ecosystems.

In the present study, the observed range in soil microbial biomass represents variations in soil microbial properties as a result of differences on soil management (Table 2). The results obtained showed a positive correlation between the improvement on the bulk density and soil chemical properties and the microbial activity, confirming results previously reported on the literature (McCarty at al., 1998).

The no-tillage system showed the highest organic matter content which was closely followed by the natural "cerrado" soil, and both differed from con-

Table 2. Bulk density, soil organic matter content, carbon microbial biomass and basal respiration on different soil management systems, at $0-10 \mathrm{~cm} \mathrm{depth}^{(1)}$.

\begin{tabular}{lcccc}
\hline $\begin{array}{l}\text { Soil management } \\
\text { system }\end{array}$ & $\begin{array}{c}\text { Bulk density } \\
\left(\mathrm{kg} \mathrm{m}^{-3}\right)\end{array}$ & $\begin{array}{c}\text { Organic matter } \\
\left(\mathrm{g} \mathrm{dm}^{-3}\right)\end{array}$ & $\begin{array}{c}\text { C-microbial biomass } \\
\left(\mu \mathrm{g} \mathrm{g}^{-1} \mathrm{dry} \text { soil }\right)\end{array}$ & $\begin{array}{c}\text { Basal respiration } \\
\left(\mu \mathrm{g} \mathrm{g}^{-1} \mathrm{day}^{-1} \mathrm{C}_{-} \mathrm{CO}_{2}\right)\end{array}$ \\
\hline No-tillage & $1,321 \mathrm{~b}$ & $42.52 \mathrm{a}$ & $469.135 \mathrm{a}$ & $4.107 \mathrm{~b}$ \\
Cerrado & $1,178 \mathrm{~d}$ & $30.57 \mathrm{~b}$ & $347.913 \mathrm{ab}$ & $5.424 \mathrm{ab}$ \\
Conventional & $1,260 \mathrm{c}$ & $24.15 \mathrm{c}$ & $315.467 \mathrm{ab}$ & $4.724 \mathrm{ab}$ \\
Pasture & $1,598 \mathrm{a}$ & $22.86 \mathrm{c}$ & $213.034 \mathrm{~b}$ & $5.950 \mathrm{a}$ \\
\hline
\end{tabular}

${ }^{(1)}$ Values followed by different letters are statistically different as $\mathrm{P} \leq 0,05$ (Tukey test) 
ventional and pasture treatments (Table 2). A similar trend for microbial biomass was probably due to the close relation between organic matter contents and microbial biomass. In no-tillage system, biological activity was also high, probably due to the amount of organic matter content in the soil. In the same way, the lowest amount of microbial biomass was detected on the pasture treatment which also presented the lowest organic matter content.

There is a considerable interest in the concept of soil quality as it relates to the use of agricultural lands in sustainable production, with the general recognition that sustainable use of agricultural land requires maintenance of the soil properties that are important for tilth and fertility (Bezdicek et al., 1996).

Active living cells need a constant supply of energy which, for heterotrophic microbiology, derives from the transformation of organic matter. Many workers have investigated the use of ratios such as C-biomass/total-C as soil quality indicators. As changes in the ratios, associated with biomass, pools appear to be more rapid and extensive than those associated with the total- $\mathrm{C}$ and $\mathrm{N}$ pools (McCarty et al., 1998).

Soil basal respiration is one of the oldest and still the most frequently used parameter for quantifying microbial activities in soils. Soil respiration is related to carbon availability in the biomass, and is generally higher at the soil surface because of greater biological activity (Saffigna et al., 1989). And the organic matter constitutes one of the most important sources of the energy and nutrients for heterotrophic microorganisms, collaborates to increase the capacity of water storage in the soil, and promotes the microbial development (Smith \& Paul, 1990).

The continuous use of the no-tillage system with crop rotation usually results in an increase of the microbial biomass and decrease in basal respiration, therefore, displaying evident long-term effects on the increase of soil C contents (Balota et al., 1998). In this study, the microbial carbon biomass and basal respiration parameters used to determine the microbial activity from soils under different management systems did not exhibit the same pattern. The no-tillage system exhibited highest concentration of $\mathrm{C}$-microbial and differed significantly $(\mathrm{P}=0.05)$ from the degraded pasture, but not from the other treatments (Table 2).
Permanent crops such as grassland generally have enhanced levels of microbial biomass, while arable crops and subsequent soil cultivation encourage biomass decline (Ayanaba et al., 1976). The permanent pasture area here studied did not exhibited the expected microbial activity probably due to the fact that pasture area was a very degraded system, and it may have been affected by effects of the grass rhizosphere on the soil (Table 2). The extensive root systems of grasses usually provide a great improvement in soil structure by binding macroaggregates with fine roots and fungal hyphae and by binding microaggregates with adhesive bacterial metabolic products. Therefore, plants growing in the soil with high improved in soil structure should produce a great microbial biomass (Perfect et al., 1990).

The interest in estimating soil microbial biomass is usually related to its function as a pool for subsequent delivery of nutrients, and its role in structure formation and stabilization of soil and as an ecological marker (Smith \& Paul, 1990). Variability in the soil respiration here measured probably resulted from multivarious mechanisms, including variability in root systems previously present in the soil, microorganism density and activity, microclimate, and substrate availability. Gradients of biological activity related to tillage differences have also been reported in other studies (Balota et al., 1998).

The results of soil samples analysis (soil properties and microbial activity) would not provide a complete understanding of the relation between soil properties and surface bio-cycling dynamic process. However, the values may be used as indicators of changes on soil quality, and parameters such as C-microbial biomass and respiration are sensitive indices to study the effect of crop systems in the soil microbiological environment. Among the studied soil management treatments, the no-tillage system exhibited better results for bulk density, soil chemical properties and $\mathrm{C}$-microbial biomass, indicating that this type of soil management system could be an alternative for recuperation and conservation of degraded "cerrado" soils.

\section{Conclusions}

1. The use and management of the soil change its physical, chemical and biological conditions.

Pesq. agropec. bras., Brasília, v. 36, n. 12, p. 1539-1545, dez. 2001 
2. The no-tillage system is more adequate in maintaining and improving the soil chemical properties.

3. Soil bulk density, when compared with the "cerrado" site (control), exhibits higher values in the pasture area, followed by no-tillage and tillage systems areas.

4. This type of soil management system can be an alternative for recuperation and conservation of degraded "cerrado" soils.

\section{References}

ALEF, K.; NANNIPIERI, P. (Ed.). Methods in applied soil microbiology and biochemistry. London: Academic, 1995. $576 \mathrm{p}$

ATLAS, R. M.; BARTHA, R. Microbial ecology. 2. ed Redwood: The Benjamin/Cummings, 1993. 563 p.

AYANABA, A.; TUCKWELL, S. B.; JENKINSON, D. S The effects of clearing and cropping on the organic reserves and biomass of tropical forest soils. Soil Biology \& Biochemistry, Oxford, v. 8, p. 519-525, 1976.

BALDOCK, J. A.; KAY, B. D. Influence of crop history and chemical treatments on the water stable aggregation of a silt loam. Canadian Journal of Soil Science, Ottawa, v. 67, p. $501-511,1987$

BALOTA, E. L.; COLOZZI-FILHO, A.; ANDRADE, D. S.; HUNGRIA, M. Biomassa microbiana e sua atividade em solos sob diferentes sistemas de preparo e sucessão de culturas. Revista Brasileira de Ciência do Solo, Campinas, v. 22, p. 641-650, 1998.

BELVINS, R. L.; SMITH, M. S.; THOMAS, G. W. Changes in soil properties under no-tillage. In: PHILLIPS, R. E.; PHILLIPS, S. H. (Ed.). No-tillage agriculture: principles and practices. New York: N. Reinhold, 1984. p. 190230 .

BEZDICEK, D. F.; PAPENDICK, R. I.; LAL, R. Introduction: importance of soil quality to health and sustainable land management. In: DURAN, J. W.; JONES, A. J (Ed.). Methods for assessing soil quality. Madison: American Society of Agronomy, 1996. p. 1-8

BLAKE, G. R. Bulk density. In: BLACK, C. A. (Ed.). Methods of soil analysis. Madison: American Society of Agronomy, 1965. p. 374-390.

CARDOSO, E. J. B. N.; TSAI, S. M.; NEVES, M. C. P. Microbiologia do solo. Campinas: Sociedade Brasileira de Ciência do Solo, 1992. 360 p.
EMBRAPA. Centro Nacional de Pesquisa de Solos (Rio de Janeiro, RJ). Sistema brasileiro de classificação do solo. Rio de Janeiro, 1999. 412 p.

JENKINSON, D. S.; LADD, J. N. Microbial biomass in soil: measurement and turnover. Soil Biology \& Biochemistry, Oxford, v. 5, p. 415-417, 1981

JENKINSON, D. S.; POWLSON, D. S. The effects of biocidal treatments on metabolism in soil. A method for measuring soil biomass. Soil Biology \& Biochemistry, Oxford, v. 8, p. 209-213, 1976

MacALADY, J. L.; FULLER, M. E.; SCOW, K. M. Effects of metam sodium fumigation on soil microbial activity and community structure. Journal of Environmental Quality, Madison, v. 27, p. 54-63, 1998

McCARTY, G. W.; LYSSENKO, N. N.; STARR, J. L. Short-term changes in soil carbon and nitrogen pools during tillage management transition. Soil Science Society of America Journal, Madison, v. 62, p. 1564-1571, 1998

PERFECT, E.; KAY, B. D.; LOON, W. K. P. van; SHEARD, R. W.; POJASOK, T. Factors influencing soil structural stability within a growing season. Soil Science Society of America Journal, Madison, v. 54, p. 173-179, 1990

POWLSON, D. S.; BROOKES, P. C.; CHRISTENSEN, B. T. Measurement of soil microbial biomass provides an early indication of changes in total soil organic matter due to straw incorporations. Soil Biology \& Biochemistry, Oxford, v. 19, p. 159-164, 1987.

POWLSON, D. S.; JENKINSON, D. S. A comparison of the organic matter, biomass, adenosine triphosphate and mineralizable nitrogen contents of ploughed and direct drilled soils. Journal of Agricultural Science, Cambridge, England, v. 97, p. 713-721, 1981

RAIJ, B. van; QUAGGIO, J. A. Métodos de análises de solos para fins de fertilidade. Campinas: Instituto Agronômico, 1993. 31 p. (Boletim Técnico, 81).

RHEINHEIMER, D. S.; KAMINSKI, J.; LUPATINI, G. C.; SANTOS, E. J. S. Modificações em atributos químicos de solo arenoso sob sistema de plantio direto. Revista Brasileira de Ciência do Solo, v. 22, p. 713-721, 1998.

SAFFIGNA, P. G.; POWLSON, D. S.; BROOKES, P. C.; THOMAS, G. A. Influence of sorghum residues and tillage on soil organic matter and soil microbial biomass in an Australian vertisol. Soil Biology \& Biochemistry, Oxford, v. 21, p. 759-765, 1989 
SIDRAS, N.; HENKLAIN, J. C.; DERPSCH, R. Comparison of three different tillage systems with respect to aggregate stability, the soil and water conservation and the yields of soybean and wheat on an oxisol. In: CONFERENCE OF THE INTERNATIONAL SOIL TILLAGE RESEARCH ORGANIZATION, 9., Osijek, 1982. Proceedings... Osijek: International Soil Tillage Research Organization, 1982. p. 537-544.

SMITH, L. J.; PAUL, E. A. The significance of soil microbial biomass estimations. In: BOLLAG, J. M.; STOTZKY, G. (Ed.). Soil biochemistry. New York: Dekker, 1990. v. 6, p. 357-396
TOMÉ JÚNIOR, J. B. Manual para interpretação de análise de solo. Guaíba: Agropecuária, 1997. 247 p.

VANCE, E. D.; BROOKES, P. C.; JENKINSON, D. S An extraction method for measuring soil microbial biomass C. Soil Biology \& Biochemistry, Oxford, v. 19, p. 703-707, 1987.

VITOUSEK, P. M.; SANFORD JUNIOR, R. L. Nutrient cycling in moist tropical forest. Annual Review of Ecology and Systematics, Palo Alto, v. 17, p. 137-167, 1986.

WORLD WILD FUND FOR NATURE (Brasília, DF) De grão em grão, o cerrado perde espaço: Cerrado impactos do processo de ocupação. Brasília, 1995. 66 p. 